its financial and material resources, support of the most important strategic industries, ensuring the growth of GDP and, consequently, sustainable growth of the welfare of the population. In the conditions of a market economy, the problem of optimal correlation of market and state regulation mechanisms is central to this task, given the need to ensure, first of all, socially vulnerable categories of citizens.

An analysis of the causes of the current state of poverty in Ukrainian society shows that overcoming it should be through raising the level and quality of life of ablebodied people, and not just the poorest sections of the population. This requires a comprehensive system of measures and appropriate changes in social protection.

The solution to the problem of poverty and low social protection in Ukraine should be related not only to economic development, but also to the existing system of social values, the effectiveness of state institutions, the effectiveness of state governance mechanisms of social development, the effectiveness of cooperation between public administration, local self-government and society, citizens. Without systematic, strategic thinking, it is impossible to implement complex reforms, it is difficult to coordinate mutually-binding components of state policy, to shape the prospects of social development.

\title{
References:
}

1. Shostak, L. V., \& Mykhaljchuk, M. O. (2018). Socialjni gharantiji jak finansovyj chynnyk zabezpechennja rivnja zhyttja naselennja [Social guarantees as a financial factor for ensuring the standard of living of the population]. Money, finance and credit, no 17, pp. 375-381.

2. Revko, A. M. (2018). Determinanty formuvannja rivnja zhyttja naselennja reghioniv Ukrajiny [Determinants of living standards of Ukrainian regions]. Scientific bulletin Polesie, pp. 154-159.

3. Tomchuk-Ponomarenko, N. (2014). Formuvannja osnovnykh naprjamiv ekonomiky dobrobutu ta rivnja zhyttja naselennja [Formation of the main directions of the welfare economy and living standards of the population]. Economy, pp. 59-65.

\section{GDP VS WEALTH: MEASURING ECONOMIC WELL-BEING}

\section{Yevheniia Kyrychenko ${ }^{1}$}

DOI: https://doi.org/10.30525/978-9934-588-11-2_66

Paul Samuelson, Nobel Laureate, described GDP as «truly among the great inventions of the 20th century, a beacon that helps policymakers steer the economy toward key economic objectives» [1]. This statement was true for more than 60 years for economists all over the world, since invention of its modern concept by Simon Kuznets in 1937. However, the chief architect of the US national accounting system cautioned that GDP should never be confused with economic and social well-being. Despite this, after Bretton Woods Conference in 1944, GDP and GDP per capita became the key indicators of economic progress, used by the IMF, the World Bank,

\footnotetext{
${ }^{1}$ Taras Shevchenko National University of Kyiv, Ukraine
} 
and the national accounting systems worldwide. However, times change, and the concepts for new measures of progress have emerged. Modern GDP criticism is generally explained by inconsistency of modern growth theories, facing new economic challenges: poor global economic growth due to increasing social inequality, wage growth slowdown, and emerging global climate risks. The problems with using GDP as a barometer go beyond masking inequality. Invented to complement the estimates of national income, facilitate wartime planning and to estimate the impact of the Great Depression, the GDP figure is a child of the manufacturing age - good at measuring physical production but not the services that dominate modern economies [2]. As the world economy transformed from manufacturing oriented to service and technically oriented, the value of the indicator diminished since it is no longer encompasses «the whole picture». This issue is particularly well described by Robert F. Kennedy in his speech at the University of Kansas, March 18, 1968: «Our Gross National Product...counts air pollution and cigarette advertising, and ambulances to clear our highways of carnage. It counts special locks for our doors and the jails for the people who break them. ... Yet the gross national product does not allow for the health of our children, the quality of their education or the joy of their play. It does not include the beauty of our poetry or the strength of our marriages, the intelligence of our public debate or the integrity of our public officials. ... it measures everything, in short, except that which makes life worthwhile» [3].

The first economist to question whether GDP accurately measures social welfare was Moses Abramovitz (1959). He cautioned that «we must be highly skeptical of the view that long-term changes in the rate of growth of welfare can be gauged even roughly from changes in the rate of growth of output». Abramovitz suggests that economists have normally operated by Pigou's dictum «that there is a clear presumption that changes in economic welfare indicate changes in social welfare in the same direction, if not in the same degree». However, he questions, what is the evidence that economic growth is positively associated with social welfare, i.e. happiness? [4, 5]. In mid-1980s, rapid GDP growth in resource-rich countries raised concern for monitoring wealth, especially natural capital, since the growth was achieved through its liquidation, leading to consumption that created no basis for sustained increase in wealth and human well-being. First steps towards GDP review as inadequate measure of economic well-being were taken in the early 2000s, mainly by Joseph Stiglitz, Nobel Laureate, who raised open discussion by his public call to put an end to «GDP fetishism» [6]. He observed that a business is always evaluated by both its income statement and its balance sheet (assets and liabilities, or wealth). Similarly, the true picture of economic health requires looking at both income and wealth. The economic performance of countries, however, is only evaluated based on national income; wealth has typically been ignored [7]. In 2008, the former French President Nicolas Sarkozy, dissatisfied with the current state of statistical information about the economy and society established the Commission on the Measurement of Economic Performance and Social Progress, or so-called Stiglitz-Sen-Fitoussi Commission. The Commission's report «Mismeasuring our lives: Why GDP Doesn't Add Up?» (2009) provided an extensive critique of GDP, with the two key messages: 
«GDP is not a good measure of wellbeing»; «what we measure affects what we do: if we measure the wrong thing, we will do the wrong thing» [8;9]. In general, current attempts to construct measures to reflect welfare can be divided into:

- corrective/complementary measures: national accounts indexes, such as GNP, GNI, GDP per capita to represent different dimensions of wellbeing which cannot be merged into one single metric;

- alternative measures: give an innovative interpretation of well-being and build new indicators to represent this concept. These include: the Human Development Index (HDI), the Gross National Happiness (GNH), the Happy Planet Index (HPI), and the Ecological Footprint EF. Each of these indexes include both income and nonincome variables such as life expectancy, environmental indicators, measures of inequality etc.

However, as mention L. Chancel and D. Demailly (2015), there is no option to replace GDP entirely: «Beyond GDP indicators only rarely play instrumental role so far. The challenge ahead will be to develop theories and statistical work to enable an instrumental use of Beyond GDP indicators» [10] In 2018, the World Bank achieved a breakthrough by introducing the comprehensive concept of wealth as a complementary indicator to GDP for monitoring sustainable development and country's welfare. The Changing Wealth of Nations 2018 report covers 141 countries over 20 years (from 1995 to 2014), and provides detailed methodology for estimation of national wealth structural components, i.e. natural, produced, human, and foreign capital [7]. The GDP/Wealth comparison table by key characteristics is given below:

Table 1

\section{GDP/Wealth comparison by key parameters}

\begin{tabular}{|c|l|l|l|}
\hline No. & Parameters & \multicolumn{1}{|c|}{ GDP } & \multicolumn{1}{c|}{ Wealth } \\
\hline $\mathbf{1}$ & Determination & $\begin{array}{l}\text { Economic output: total } \\
\text { amount of goods and } \\
\text { services produced by } \\
\text { country's residents over } \\
\text { specific period. }\end{array}$ & $\begin{array}{l}\text { Country's balance sheet: total value } \\
\text { of country's stocks with either yields } \\
\text { (income) or burdens and drafts (debts, } \\
\text { taxation, indemnities, etc.) over } \\
\text { specific period. }\end{array}$ \\
\hline $\mathbf{2}$ & Interpretation & $\begin{array}{l}\text { Quantity indicator of } \\
\text { economic growth. }\end{array}$ & $\begin{array}{l}\text { Quality indicator of economic and } \\
\text { social wellbeing. Shows proportions } \\
\text { between structural elements } \\
\text { constituting national wealth. }\end{array}$ \\
\hline $\mathbf{3}$ & $\begin{array}{l}\text { Calculation } \\
\text { Formula }\end{array}$ & $\begin{array}{l}\text { GDP (Y) }=\text { Consumption } \\
\text { (C) + Investment (I) }+ \\
\text { Government (G) }+ \text { Net } \\
\text { Exports (NX) }\end{array}$ & $\begin{array}{l}\text { Wealth (W) } \text { Human capital (HC) }+ \\
\text { Produced Capital (PC) + Natural } \\
\text { Capital (NC) + Net foreign assets } \\
\text { (NFA) }\end{array}$ \\
\hline $\mathbf{4}$ & $\begin{array}{l}\text { Accounting } \\
\text { differences }\end{array}$ & $\begin{array}{l}\text { Analogue to cash flow } \\
\text { statement. }\end{array}$ & $\begin{array}{l}\text { Analogue to balance sheet. Takes into } \\
\text { account not only wages, but all assets } \\
\text { (cash, investment, real estate, other } \\
\text { assets) and nation's liabilities } \\
\text { (mortgage, student loans, car loans, } \\
\text { credit card balances). }\end{array}$ \\
\hline
\end{tabular}




\begin{tabular}{|c|l|l|l|}
\hline $\mathbf{5}$ & $\begin{array}{l}\text { Relationship } \\
\text { to economic } \\
\text { growth }\end{array}$ & $\begin{array}{l}\text { Shows the growth of } \\
\text { consumption, exports and } \\
\text { public spending. }\end{array}$ & $\begin{array}{l}\text { Displays changes in household } \\
\text { income and savings rate. Serves as an } \\
\text { integral indicator for sustainable } \\
\text { development, reflecting the country's } \\
\text { overall long-term resource and } \\
\text { economic potential in the form of } \\
\text { assets. }\end{array}$ \\
\hline $\mathbf{6}$ & Applicability & $\begin{array}{l}\text { Standardized calculation } \\
\text { methodology included in } \\
\text { SNA. }\end{array}$ & $\begin{array}{l}\text { Absence of standardized methods for } \\
\text { determining the indicator, complexity } \\
\text { of calculation. Volatility due to } \\
\text { dependence on human capital (key } \\
\text { structural component). }\end{array}$ \\
\hline
\end{tabular}

Source: developed by the author

Therefore, national wealth accounting is crucial for tracking countries sustainability. The World Bank uses wealth and wealth per capita as «to be improved» indicators of sustainability, which can accurately measure economic progress and complement GDP.

\section{References:}

1. Landefeld, J.S. (2000). GDP: One of the Great Inventions of the $20^{\text {th }}$ Century. Federal Reserve Bank of St. Louis. Retrieved from https://fraser.stlouisfed.org/files/docs/publications/SCB/ pages/2000-2004/35260_2000-2004.pdf (accessed 29 September 2019).

2. Costanza, R., Hart, M., Kubiszewski, I. (2014). A Short History of GDP: Moving Towards Better Measures of Human Well-being. Solutions. Retrieved from https://www.thesolutionsjournal.com/article/a-short-history-of-gdp-moving-towards-better-measuresof-human-well-being/ (accessed 29 September 2019).

3. Rogers, S. (2012). Bobby Kennedy on GDP: 'measures everything except that which is worthwhile'. The Guardian. Retrieved from https://www.theguardian.com/news/datablog/ 2012/may/24/robert-kennedy-gdp (accessed 29 September 2019).

4. Abramovitz, M. (1959). The welfare interpretation of secular trends in national income and product. In The Allocation of economic resources: Essays in honour of Bernard Francis and Haley (M. Abramovitz et. al.). Stanford, California: Stanford Univ. Press.

5. Easterlin, R. A. (1974). Does Economic Growth Improve the Human Lot? Some Empirical Evidence. University of Pennsylvania. Retrieved from http://huwdixon.org/teaching/cei/ Easterlin1974.pdf (accessed 29 September 2019).

6. Stiglitz, J. E. (2009). GDP Fetishism. The Economists' Voice. Retrieved from http://folk.uio.no/sholden/E1310/gdp-fetishism-stiglitz.pdf (accessed 29 September 2019).

7. Lange, G., Wodon, Q., Carey, K. (2018). The Changing Wealth of Nations 2018. Build a Sustainable Future. World Bank Retrieved from https://openknowledge.worldbank.org/bitstream/ handle/10986/29001/9781464810466.pdf (accessed 29 September 2019).

8. OECD (2018). Beyond GDP: Measuring what counts for economic and social performance. OECD Publishing, Paris. doi: https://doi.org/10.1787/ 9789264307292-en

8. Stiglitz, J. E. (2018). GDP is not a good measure of wellbeing. The Guardian. Retrieved from https:/www.theguardian.com/business/2018/dec/03/gdp-wellbeing-health-education-environmentjoseph-stiglitz (accessed 29 September 2019).

10. Chancel, L., Demailly, D. (2015). Beyond GDP indicators: to what end? IDDRI. Retrieved from https://www.iddri.org/sites/default/files/import/publications/st0414en.pdf (accessed 29 September 2019). 